\title{
STUDY OF RAT HEPATOCYTES IN PRIMARY CULTURE SUBMITTEDTO HYPOXIA AND REOXYGENATION: action of the cytoprotectors prostaglandin E1, superoxide dismutase, allopurinol and verapamil
}

\author{
Dahir Ramos de ANDRADE Jr., Dahir Ramos de ANDRADE and Sânia Alves dos SANTOS
}

\begin{abstract}
Context - Exposure of hepatocytes to pathological conditions in a microenvironment of hypoxia and reoxygenation is very frequent in hepatic diseases. Several substances present perspectives for cytoprotective action on hepatocyte submitted to reoxygenation after hypoxia and simple hypoxia. Objective - We research therapeutic options for hepatocytes submitted to hypoxia and hypoxia + reoxygenation injury. Methods - Primary culture of rat hepatocytes was submitted to hypoxia ( 2 hours) plus reoxygenation ( 2 hours) and simple hypoxia (4 hours) in the presence or the absence of cytoprotectors. The hepatocyte lesion was evaluated by functional criteria through percentage of lactate dehydrogenase released and cell viability. The effects of the cytoprotectors prostaglandin E1 $3 \eta \mathrm{g} / \mathrm{mL}$, superoxide dismutase $80 \mu \mathrm{g} / \mathrm{mL}$, allopurinol $20 \mu \mathrm{M}$ and verapamil $10^{-4} \mathrm{M}$ were studied in this model of injury. Results - Reoxygenation after hypoxia induced more significant lesion in cultured hepatocytes compared to simple hypoxia, detected by analysis of functional criteria. There was a significant reduction of percentage of lactate dehydrogenase released and a significant increase of percentage of cell viability in the hypoxia + reoxygenation + cytoprotectors groups compared to hypoxia + reoxygenation groups. Prostaglandin E1, superoxide dismutase and verapamil also protected the group submitted to simple hypoxia, when evaluated by functional criteria. Conclusions - We conclude that reoxygenation after hypoxia significantly increased the lesion of cultured rat hepatocytes when compared to simple hypoxia. Prostaglandin E1, superoxide dismutase, allopurinol and verapamil acted as cytoprotectors to the rat cultured hepatocytes submitted to hypoxia + reoxygenation in vitro. The substances prostaglandin E1, superoxide dismutase and verapamil protected hepatocytes submitted to simple hypoxia on the basis of all the criteria studied in this experimental model.
\end{abstract}

HEADINGS - Hepatocytes. Cell hypoxia. Prostaglandins E. Superoxide dismutase. Allopurinol. Verapamil. Rats.

\section{INTRODUCTION}

The study of cell injury caused by simple hypoxia and by reoxygenation after hypoxia has been of great interest. Exposure of hepatocytes to pathological conditions in a microenvironment of hypoxia and reoxygenation is very frequent in several hepatic diseases. In hemodynamic shock, fulminant hepatitis, cardiac and pulmonary failure, septicemia, systemic inflammatory response syndrome and in the conservation of graft for transplant, a microenvironment of hypoxia/anoxia will appear followed by reoxygenation which can be injurious to the liver cell. Death of hepatocytes by hypoxia and hypoxia plus reoxygenation injury seems to be a multifactorial event including alterations of the plasma membrane, increase of autophagic vacuoles, leakage of lysosomal enzymes, rupture of blebs on the cell surface, calcium accumulation in the intracellular medium with activation of hydrolytic enzymes, and extensive mitochondrial damage ${ }^{(5,17,19,33,64)}$. Knowledge about cell damage induced by reoxygenation after hypoxia advanced with the description of oxygen free radicals (OFRs), such as hydroxyl $(\bullet \mathrm{OH})$, superoxide $\left(\mathrm{O}_{2}^{-} \cdot\right)$ and perhydroxyl $\left(\mathrm{HO}_{2}^{-}\right)$free radicals ${ }^{(64)}$. OFRs are formed in reoxygenation environments mainly coming from the mitochondrial respiratory chain and from cytoplasmatic sources. Excessive production of OFRs may exceed the defensive mechanism of the cell, causing lipid peroxidation with structural damage of the cell membranes, as well as severe disarrangement of proteins, carbohydrates and DNA ${ }^{(17,61,64)}$.

Many substances may have cytoprotective action on hepatocyte submitted to reoxygenation after hypoxia and simple hypoxia. The prostaglandin E1 (PGE1),

\footnotetext{
Financial support: The principal author received financial support from Brazilian Institutions: CNPq ("Conselho Nacional de Desenvolvimento Científico e Tecnológico") and FAPESP ("Fundação de Amparo à Pesquisa do Estado de São Paulo").

"Departamento de Moléstias Infecciosas e Parasitárias, Laboratório de Bacteriologia - LIM 54, Faculdade de Medicina. Universidade de São Paulo", São Paulo, Brazil. Correspondence: Dr. Dahir Ramos de Andrade Jr., MD - Rua Emboaçava, 358 - apt.101 - Mooca - 03124-010 - São Paulo, SP, Brazil. E-mail: dahira@uol.com.br
} 
superoxide dismutase (SOD), allopurinol (ALO) and verapamil (VERA) were evaluated in this study. Prostaglandins (PGs) and prostacyclin have been studied in various injury models such as isolated hepatocytes under anoxia, liver perfusion ischemia, fulminant hepatitis, hepatic necrosis, liver lesion by drugs, among others ${ }^{(1,2,21,22,31,37,52,53,54,58)}$. However, there are few studies employing PGs in primary culture of hepatocytes $^{(3)}$. The effects of SOD enzyme, which neutralizes the action of superoxide radicals, were studied in few studies carried out mainly with the perfused liver model ${ }^{(9,28,29,45,63)}$. KOBAYASHI and CLEMENS ${ }^{(30)}$ studied the effects of SOD in the hepatocyte culture model when submitted to hypoxia followed by reoxygenation. There are not studies about the SOD effects on simple hypoxia in the literature. ALO has a well-known action in the blockade of xanthine oxidase (XO) enzyme and it has a cytoprotective potential against injury provoked by reoxygenation. Few studies are available about ALO effect on hepatocytes submitted to reoxygenation injury, mainly in the primary culture model. Several authors ${ }^{(8 .}$ 44, 63, 64) studied the ALO effect on the perfused liver model under ischemia/reperfusion. CARACENI et al. ${ }^{(7)}$ showed the effects of ALO on isolated hepatocyte. This drug was also employed in studies with other organs such as the heart ${ }^{(12)}$ and the kidney ${ }^{(11)}$. The effects of ALO in a microenvironment of simple hypoxia have not been referred in the medical literature. VERA has a calcium channel blocking activity and the calcium can influence the injury provoked by hypoxia plus reoxygenation. A great number of studies about VERA utilized the ischemia/reperfusion model ${ }^{(14,42,55,57)}$.

In the present study, cultured hepatocytes were exposed to hypoxia for 2 hours and reoxygenation for 2 hours and compared with simple hypoxia for 4 hours, and also with control groups, in the presence or the absence of the substances under investigation. Analysis by functional criteria showed that PGE1, SOD, ALO and VERA had a cytoprotective action on cultured hepatocytes exposed to reoxygenation after hypoxia.

\section{METHODS}

\section{A) Primary culture of rat hepatocytes}

Newborn female rats up to 1 week old were used. All animals received care according to the National Institute of Health guidelines for the care and use of laboratory animals. The animals were anesthetized with eter and operated upon using an aseptic technique under a laminar airflow. The liver was transferred to $\mathrm{Ca}^{2+}$-free and $\mathrm{Mg}^{2+}$-free phosphate buffered saline (PBS). The organs were fragmented with a pair of scissors for 10 minutes (min), and centrifuged at low rotation for $5 \mathrm{~min}$ in a cold centrifuge (Hitachi). The supernatant was discarded, and the material was incubated with $0.2 \%$ collagenase (Sigma) for $10 \mathrm{~min}$ in a stove at $37^{\circ} \mathrm{C}$. After this a $20 \%$ solution of PBS + fetal bovine serum (FBS) (Cultilab) was added and the material was centrifuged for $5 \mathrm{~min}$ at low rotation. The supernatant was discarded. This operation was repeated three times and the material was transferred to plastic culture bottles (Nunc) previously covered with the laminin matrix (Sigma) at $50 \mu \mathrm{g} / \mathrm{ml}$ concentration. Culture medium Williams E (Sigma) was utilized containing 2\% (v/v) FBS and supplemented with: $10^{-8} \mathrm{M}$ Insulin (Sigma), $10^{-9} \mathrm{M}$ Glucagon (Sigma), $10 \mu \mathrm{U} / \mathrm{mL}$ Human Growth Hormone (Sigma), 10 $\eta \mathrm{g} / \mathrm{mL}$ Epidermal Growth Factor (Sigma), $30 \mathrm{mg} / \mathrm{mL}$ Proline (Sigma), $100 \mu \mathrm{g} / \mathrm{mL}$ Crystalline Penicillin (Fontoura-Wyeth), $100 \mu \mathrm{g} / \mathrm{mL}$ Streptomycin (Sigma), $5 \mu \mathrm{g} / \mathrm{mL}$ Amphotericin B (Squibb), $1 \mathrm{~g} / \mathrm{L}$ HEPES (Sigma), $1 \mathrm{~g} / \mathrm{L}$ sodium bicarbonate (Sigma) and $5 \times 10^{-8} \mathrm{M}$ of hydrocortisone (Sigma). The final atmosphere in the bottles had 95\% air and 5\% $\mathrm{CO}_{2}$. The bottles were then placed in a $\mathrm{CO}_{2}$ stove (Nuaire) during 24 hours at $37^{\circ} \mathrm{C}$. The Williams E medium was again changed on the 4 th and 5 th day.

\section{B) Cell Indexes}

Cell viability was measured by the technique using $0.4 \%$ Trypan-Blue stain exclusion. The viable cells (unstained) and the non-viable cells (stained) were counted in a Neubauer chamber. The results are reported as cell viability percentage and calculated by the following formula:

$$
\% \text { Cell Viability }=\text { Number of viable cells (unstained) }
$$
Number of viable + non viable cells (stained)

Cell viability was calculated on the 1 st day and also on the 5th day before and after the experimental assay. Confirmation of the hepatic cell culture was performed by immunohistochemistry technique using the streptavidin - biotin - peroxidase method. Lactate dehydrogenase (LDH) isozymes in the bottle supernatant were determined by electrophoresis on acetate strips. Albumin levels in the supernatant were determined by nephelometry using a Nephelometer Analyzer (Behring) on the 8th day of culture.

\section{C) Experimental assay under hypoxia and reoxygenation}

The rat hepatocytes in primary culture were utilized on the 5th culture day. The culture medium of each bottle was changed immediately before the procedure and $\mathrm{pH}$ was adjusted by adding HEPES. Hypoxia was established by the nitrogen $\left(\mathrm{N}_{2}\right)$ bubbling technique in the culture bottles and carried out for $60 \mathrm{~min}$ with bottle shaking at each $5 \mathrm{~min}$. After $\mathrm{N}_{2}$ bubbling there was a significant drop of the $\mathrm{PO}_{2}$ in the bottles from 196.5 to $62.3 \mathrm{~mm} \mathrm{Hg}$. The $\mathrm{PO}_{2}$ was measured with a "Stat Profile plus 3" gas analysis apparatus (New Biomedical, USA) in aliquots of the culture medium. At the end of the procedure the bottles were closed and placed in a stove at $37^{\circ} \mathrm{C}$ for 2 or 4 hours according to the experimental group. In the groups selected for reoxygenation the bottles were bubbled with carbogen gas $\left(95 \% \mathrm{O}_{2}, 5 \% \mathrm{CO}_{2}\right)$ for $30 \mathrm{~min}$. $\mathrm{PO}_{2}$ after bubbling with carbogen and reached an average of $464.9 \mathrm{~mm} \mathrm{Hg}$. After this period, the medium $\mathrm{pH}$ was adjusted with a sodium bicarbonate solution, and the bottles were closed again and incubated in a stove at $37^{\circ} \mathrm{C}$ for $2 \mathrm{~h}$. The following study groups were formed: 2 hour hypoxia + 2 hour reoxygenation $(\mathrm{H}+\mathrm{R}), 4$ hour simple hypoxia $(\mathrm{H})$, simple control, $\mathrm{H}+\mathrm{R}+$ cytoprotectors, $\mathrm{H}+$ cytoprotectors 
and control + cytoprotectors. Both 2 hour hypoxia group that was not followed by reoxygenation and 2 hour oxygenation without hypoxia group were made in order to prove the utility of injury times of this study.

\section{D) Functional criteria employed in the study of hepatocyte lesion}

The functional criteria utilized to measure the lesion of hepatocytes submitted to injury caused by simple hypoxia and hypoxia + reoxygenation were: the percentage of $\mathrm{LDH}$ enzyme released and the percentage of cell viability which was measured by the technique of Trypan-Blue stain exclusion as mentioned in item B. LDH was measured by the ultraviolet spectrophotometric method both in the supernatant and in the intracellular medium. The percentage of the enzyme released was calculated by the formula:

\section{\% Released Enzyme = Supernatant Enzyme Supernatant Enzyme + Intracellular Enzyme}

The technique for LDH determination was as follows: at the end of the incubation period, the supernatant was transferred to conic plastic tubes which were centrifuged at $5000 \mathrm{rpm}$ for $3 \mathrm{~min}$. One $\mathrm{mL}$ aliquots of supernatant were placed in Eppendorf tubes for a later LDH determination. In order to measure the enzyme in the intracellular medium, the hepatocytes were removed from each bottle using a $0.2 \%$ trypsin and $0.02 \%$ versen solution. The contents of each bottle were transferred to the respective conic tubes containing the supernatant, and were centrifuged at $5000 \mathrm{rpm}$ for $4 \mathrm{~min}$. The pellet was resuspended in $0.5 \mathrm{~mL}$ of PBS and placed in Eppendorf tubes. The supernatant was removed and $0.2 \mathrm{~mL}$ $1 \%$ Triton X-100 was added for $30 \mathrm{~min}$ to induce cell rupture.

LDH enzyme was determined by the BEUTLER ${ }^{(6)}$ method modified. The following reagents were utilized: 1 $\mathrm{M}$ Tris - HCL $+5 \mathrm{mM}$ EDTA $=100 \mu \mathrm{L}, 2 \mathrm{mM} \mathrm{NADH}$ $=100 \mu \mathrm{L}, 10 \mathrm{mM}$ Sodium Piruvate $=100 \mu \mathrm{L}$. The sample volume was $200 \mu \mathrm{L}$ for the extracellular enzyme and $50 \mu \mathrm{L}$ for the intracellular enzyme. The reaction was read with an ultraviolet spectrophotometer every $10 \mathrm{~s}$ for $60 \mathrm{~s}$ at $340 \mathrm{~nm}$ wavelength at $25^{\circ} \mathrm{C}$. All readings were made in duplicate. Each culture bottle produced an individual value of percent LDH released in each experimental group.

An aliquot was removed from Eppendorf tubes to calculate cell viability before incubation with Triton X-100 and added to $0.4 \%$ Trypan-Blue stain for $5 \mathrm{~min}$. Stained and unstained cells were counted in a Neubauer chamber, and cell viability was calculated by the formula mentioned above.

\section{E) Experimental assay with cytoprotectors}

The cytoprotectors employed in this experimental model were: Prostaglandin E1 (PGE1) (Sigma) $3 \eta \mathrm{g} / \mathrm{mL}$, Superoxide Dismutase (SOD) (Sigma) $80 \mu \mathrm{g} / \mathrm{mL}$, Allopurinol (ALO) (Sigma) $20 \mu \mathrm{M}$ and Verapamil (VERA) $10^{-4} \mathrm{M}$. The final drugs doses were defined after pilot-assays with four doses per group. The above substances were added to the bottles on the 5 th day of culture and they were pre-incubated for $2 \mathrm{~h}$ before the beginning of hypoxia and immediately after changing the culture medium. The substances were placed in bottles of the following experimental groups: $\mathrm{H}+\mathrm{R}, \mathrm{H}$ and control.

\section{F) FOX method}

The hydroperoxides measurement was made by FOX2 (ferrous oxidation in xylenol orange) method as described for WOLFF ${ }^{(62)}$ with modifications. The components of the solution utilized (FOX2 reagent) in the assay were $100 \mu \mathrm{M}$ xylenol orange (Sigma), $250 \mu \mathrm{M}$ ammonium ferrous sulfate (Sigma), 90\% methanol (Merck), 4mM butylated hydroxytoluene (Sigma), $25 \mathrm{mM} \mathrm{H}_{2} \mathrm{SO}_{4}$ (Merck). A hundred microliters of each sample were added to $950 \mu \mathrm{L}$ of FOX2 reagent, vortexed, and incubated at room temperature for $30 \mathrm{~min}$. The absorbance was read at $560 \mathrm{~nm}$ after brief centrifugation. The signal was read against a $\mathrm{H}_{2} \mathrm{O}_{2}$ standard curve. The final results were expressed in $\mu \mathrm{M}$ of hydroperoxides per mg of protein.

\section{G) Statistical analysis}

The data concerning $\mathrm{LDH}$ released and cell viability percentages were compared by a nonparametric test, owing to the lack of Gaussian distribution. The unpaired Mann-Whitney test was used to compare two distinct groups. The Kruskal-Wallis multiple comparisons test and Dunn's posttest was used when comparing two or more unpaired groups. An equal or lower alpha risk of $5 \%(P \leq 0.05)$ was considered statistically significant. The values were expressed as median and sample variability is reported as $25 \%$ and $75 \%$ percentiles. The results were presented in tables with numbers in percentiles and medians.

\section{RESULTS}

\section{Cellular indexes of hepatocyte culture}

Cell viability on the 1st day reached $95 \%$ of the hepatocytes with good morphological aspect observed by LM. The cell count showed an average number of $4.01 \times 10^{8}$ hepatocytes $/ \mathrm{mL}$. Cell viability on the 5th day (experimental assay) was $91.92 \%$ with $1.8 \times 10^{6}$ hepatocytes $/ \mathrm{mL}$. The immunohistochemical test carried out on cultured hepatocytes showed positive results for cytokeratin AE1 and AE3. Furthermore, LDH isozymes were determined in the bottle supernatant, with predominance of fraction 5 of the enzyme (72.2\%). The dosage of albumin in the bottle supernatant was positive $(49.8 \mathrm{mg} / \mathrm{L})$.

\section{Comparison among control groups}

There was no significant difference in percent LDH released between the simple control and control + cytoprotectors (C-PGE1, C-SOD, C-ALO and C-VERA) groups (Table 1). Similarly, no significant difference in percent cell viability was observed between the simple control group and the control + cytoprotectors groups (Table 2 ).

\section{3) Comparison among the control, simple hypoxia and hypoxia + cytoprotectors groups}

Analysis of percent LDH released showed a significant difference between the hypoxia $(4 \mathrm{~h})=40.85 \%(37.25$ $42.85)(\mathrm{n}=13)$ and control $=15.27 \%(9.81-18.56)(\mathrm{n}=19)$ 
TABLE 1. Comparison of percent LDH released between groups: simple control and control + cytoprotectors

\begin{tabular}{lccc}
\hline Groups & $\mathrm{n}^{*}$ & Median & Range $\dagger$ \\
\hline Control & 19 & 15.27 & $9.81-19.09$ \\
Control + PGE1 & 11 & 18.64 & $14.46-22.67$ \\
Control + SOD & 10 & 18.08 & $13.96-22.20$ \\
Control + ALO & 10 & 21.44 & $10.35-24.69$ \\
Control + VERA & 10 & 14.82 & $12.07-17.27$ \\
\hline
\end{tabular}

NOTE: Comparison between Control and Control + Drug groups $=P>0.05$ (NS) (Kruskal-Wallis); ${ }_{\mathrm{n}}=$ number of assays. $\dagger$ $25 \%$ to $75 \%$ percentil

TABLE 2. Comparison of percent cell viability between groups: simple control and control + cytoprotectors

\begin{tabular}{lccc}
\hline Groups & $\mathrm{n}^{*}$ & Median & Range $\dagger$ \\
\hline Control & 12 & 78.91 & $76.17-86.05$ \\
Control + PGE1 & 12 & 75.92 & $74.68-77.96$ \\
Control + SOD & 12 & 85.71 & $84.61-87.88$ \\
Control + ALO & 12 & 78.31 & $73.47-82.46$ \\
Control + VERA & 12 & 77.11 & $74.71-80.70$ \\
\hline NOTE: Comparison between Control and Control + Drug groups $=P>0.05$ (NS) (Kruskal-Wallis); * = number of assays; $\dagger=$
\end{tabular}

$25 \%$ to $75 \%$ percentil

$(P<0.001)$ groups. Comparison between $4 \mathrm{~h}$ hypoxia $(\mathrm{SH}-4)$ $=40.85 \%(37.25-42.85)(\mathrm{n}=13)$ and $2 \mathrm{~h}$ hypoxia $(\mathrm{SH}-2)=$ $24.03 \%(16.66-26.42)(\mathrm{n}=13)$ groups revealed a significant difference $(P<0.0001)$. Among the hypoxia + cytoprotectors groups studied, $\mathrm{H}+\mathrm{ALO}=26.0 \%(23.85-36.75)(\mathrm{n}=15)$ and $\mathrm{H}+$ VERA $=24.17 \%(23.62-28.36)(\mathrm{n}=17)$ presented a significant difference compared to the simple control group. No difference was observed between groups $\mathrm{H}+$ PGE1 = $19.69 \%(13.62-22.75)(\mathrm{n}=17)$ and $\mathrm{H}+\mathrm{SOD}=22.55 \%(18.94$ - 23.73) $(n=21)$ and the control group. The cytoprotectors PGE1, SOD and VERA significantly reduced the lesion of groups under hypoxia compared to simple hypoxia $(P<0.001$, $P<0.001$ and $P<0.05$, respectively). This did not occur with group H + ALO in relation to percent LDH released.

Percent cell viability showed a significant difference between the hypoxia $=61.60 \%(55.16-65.89)(\mathrm{n}=20)$ and control $=78.91 \%(76.17-86.05)(\mathrm{n}=12)(P<0.001)$ groups, and between $4 \mathrm{~h}$ hypoxia $=61.60 \%(55.16-65.89)(\mathrm{n}=20)$ and $2 \mathrm{~h}$ hypoxia $=88.35 \%(82.92-89.67)(\mathrm{n}=12)(P<0.0001)$ groups as well. The control and $2 \mathrm{~h}$ hypoxia groups were not significantly different $(P>0.05)$. The results also revealed that all cytoprotectors improved markedly the cell viability of groups under hypoxia, with no significant difference between them and the control group. A significant improvement in cell viability was noted between groups: $\mathrm{H}+\mathrm{PGE} 1=79.79 \%$ $(76.19-81.63)(\mathrm{n}=13), \mathrm{H}+\mathrm{SOD}=82.87 \%(80.18-86.81)$ $(\mathrm{n}=12), \mathrm{H}+\mathrm{ALO}=78.16 \%(73.22-84.24)(\mathrm{n}=12), \mathrm{H}+$ VERA $=79.70 \%(76.15-82.74)(\mathrm{n}=10)$ and the simple hypoxia group $=61.60 \%(55.16 \mathrm{~B} 65.89)(\mathrm{n}=20)$.

\section{4) Analysis of the control, hypoxia + reoxygenation $(\mathrm{H}+\mathrm{R})$ and hypoxia + reoxygenation + cytoprotectors (H+R+Cy) groups}

A significant difference in percent $\mathrm{LDH}$ released was observed between groups $\mathrm{H}+\mathrm{R}=48.50 \%(44.0-51.98)(\mathrm{n}=$ $14)$ and control $=15.27 \%(9.81-18.56)(\mathrm{n}=19)(P<0.001)$ as well as between $\mathrm{H}+\mathrm{R}$ group and $2 \mathrm{~h}$ oxygenation group $=14.04 \%(8.33-25.20)(\mathrm{n}=12)(P<0.0001)$. There was no significant difference between the control group and $2 \mathrm{~h}$ oxygenation group in relation to the percent $\mathrm{LDH}$ released $(P=0.9)$. PGE1 and SOD were found to have a strong protective effect on groups $\mathrm{H}+\mathrm{R}+\mathrm{PGE} 1=19.63 \%$ $(13.04-27.12)(\mathrm{n}=17)$ and $\mathrm{H}+\mathrm{R}+\mathrm{SOD}=25.42 \%(20.75$ - 31.64) $(n=21)$, with no significant difference from the control group. The results showed that the substances PGE1, SOD, ALO and VERA were cytoprotectors when groups $\mathrm{H}+\mathrm{R}+\mathrm{Cy}$ and $\mathrm{H}+\mathrm{R}=48.50 \%(44.0-51.98)(\mathrm{n}=$ 14) were compared (Table 3 ).

Percent cell viability again differed between $\mathrm{H}+\mathrm{R}=57.32 \%$ $(54.19-59.46)(\mathrm{n}=20)$ and control $=78.91 \%(76.17-86.05)(\mathrm{n}$ $=12)(P<0.001)$. There was also a difference between the $\mathrm{H}+\mathrm{R}$ group and the $2 \mathrm{~h}$ oxygenation group $=81.65 \%(80.32-88.55)$ $(\mathrm{n}=12)(P<0.001)$. In contrast, no significant difference was obtained between the control group and the $2 \mathrm{~h}$ oxygenation group $(P=0.18)$. There was also no significant difference between the following groups: $\mathrm{H}+\mathrm{R}+\mathrm{PGE} 1, \mathrm{H}+\mathrm{R}+\mathrm{SOD}$, $\mathrm{H}+\mathrm{R}+\mathrm{ALO}, \mathrm{H}+\mathrm{R}+\mathrm{VERA}$ and the control group (Table 4). The results also showed that PGE1, SOD, ALO and VERA

TABLE 3. Comparison of percent LDH released among groups: simple control, $\mathrm{H}+\mathrm{R}$ and $\mathrm{H}+\mathrm{R}+$ cytoprotectors

\begin{tabular}{|c|c|c|c|c|c|}
\hline Groups & $\mathrm{n}^{*}$ & Median & Range $\dagger$ & Controlł & $\mathrm{H}+\mathrm{R}^{* * *}$ \\
\hline $\mathrm{H}+\mathrm{R}+\mathrm{PGE} 1$ & 17 & 19.63 & $13.04-27.12$ & NSף & $P<0.001$ \\
\hline $\mathrm{H}+\mathrm{R}+\mathrm{SOD}$ & 21 & 25.42 & $20.75-31.64$ & NS & $P<0.001$ \\
\hline $\mathrm{H}+\mathrm{R}+\mathrm{ALO}$ & 19 & 34.46 & $22.37-38.67$ & $P<0.01$ & $P<0.05$ \\
\hline $\mathrm{H}+\mathrm{R}+$ VERA & 19 & 32.67 & $25.49-36.98$ & $P<0.01$ & $P<0.01$ \\
\hline
\end{tabular}

NOTE: $*=$ number of assays; $\uparrow=25 \%$ to $75 \%$ percentile; $\ddagger$ - Control group $=15.27 \%(9.81-18.56)(\mathrm{n}=19) ; * *-\mathrm{H}+\mathrm{R}$ group $=48.50 \%(44.0-51.98)(\mathrm{n}=14) ; \mathfrak{\uparrow}=$ non significant

TABLE 4. Comparison of percent cell viability among groups: simple control, $\mathrm{H}+\mathrm{R}$ and $\mathrm{H}+\mathrm{R}+$ cytoprotectors

\begin{tabular}{|c|c|c|c|c|c|}
\hline Groups & $\mathrm{n}^{*}$ & Median & Range $\dagger$ & Controlf & $\mathrm{H}+\mathrm{R}^{* *}$ \\
\hline $\mathrm{H}+\mathrm{R}+\mathrm{PGE} 1$ & 10 & 73.38 & $70.24-74.24$ & NS & $P<0.05$ \\
\hline $\mathrm{H}+\mathrm{R}+\mathrm{SOD}$ & 10 & 71.29 & $70.00-73.35$ & NS & $P<0.05$ \\
\hline $\mathrm{H}+\mathrm{R}+\mathrm{ALO}$ & 10 & 72.80 & $70.00-75.38$ & NS & $P<0.05$ \\
\hline $\mathrm{H}+\mathrm{R}+$ VERA & 12 & 84.26 & $79.84-85.54$ & NS & $P<0.001$ \\
\hline
\end{tabular}

NOTE: $*$ = number of assays; $\dagger=25 \%$ to $75 \%$ percentile; $\ddagger-$ Control group $=78.91 \%(76.17-86.05)(\mathrm{n}=12) ; *-\mathrm{H}+\mathrm{R}$ group $=57.32 \%(54.19-59.46)(\mathrm{n}=20) ; \boldsymbol{\Phi}=$ non significant 
significantly improved the cell viability of theirs $\mathrm{H}+\mathrm{R}$ groups as compared with $\mathrm{H}+\mathrm{R}$ group (Table 4 ).

\section{5) Comparison among simple hypoxia (SH), hypoxia + reoxygenation $(\mathrm{H}+\mathrm{R})$, hypoxia + cytoprotectors $(\mathrm{H}+\mathrm{Cy})$, and hypoxia + reoxygenation + cytoprotectors $(\mathrm{H}+\mathrm{R}+\mathrm{Cy})$ groups}

There was a significant difference in percent LDH released between simple hypoxia and $\mathrm{H}+\mathrm{R}$ groups $(P<0.05)$. No difference was observed between groups $\mathrm{SH}+\mathrm{Cy}$ and $\mathrm{H}+\mathrm{R}+\mathrm{Cy}$. The $\mathrm{SH}$ groups $($ median $=61.60 \%)$ and $\mathrm{H}+\mathrm{R}($ median $=57.32 \%)$ were also significantly different in terms of percent cell viability. In the comparative analysis of percent cell viability between groups $\mathrm{SH}+\mathrm{Cy}$ and $\mathrm{H}+\mathrm{R}+\mathrm{Cy}$ there was lower cell viability in groups $\mathrm{H}+\mathrm{R}+\mathrm{Cy}$ versus $\mathrm{H}+\mathrm{Cy}(P<0.05)$.

\section{6) Hydroperoxides measurement in the $H+R+P G E 1$ groups}

The values of hydroperoxide/protein $(\mu \mathrm{M} / \mathrm{mg})$ obtained by FOX-2 method were: control $=8.0(0.0-23.0)(\mathrm{n}=5)$; $\mathrm{H}+\mathrm{R}=82.0(57.0-87.0)(\mathrm{n}=5) ; \mathrm{H}+\mathrm{R}+\mathrm{PGE} 1=53.0(10-136)$ $(\mathrm{n}=5)$. There was a significant difference between control and $\mathrm{H}+\mathrm{R}$ groups $(P<0.05)$, but no difference was obtained between $\mathrm{H}+\mathrm{R}$ and $\mathrm{H}+\mathrm{R}+\mathrm{PGE} 1$ groups $(P>0.05)$.

\section{DISCUSSION}

The experimental injury model used in this study demonstrated efficiency in inducing lesion in cultured hepatocytes, analyzed by functional criteria. Both injury groups ( $\mathrm{SH}$ and $\mathrm{H}+\mathrm{R}$ ) were different from the control group in terms of percent LDH released and percent cell viability. The percentage of LDH released is a cytotoxic index that mainly reflects the integrity of the plasma membrane ${ }^{(26)}$. The results of this index are generally closely related to the percentage of cell viability measured by Trypan-Blue stain exclusion $^{(20,26)}$. The $\mathrm{H}+\mathrm{R}$ groups showed clearly that reoxygenation caused more severe damage compared to $\mathrm{SH}$ during the periods studied in this work: 2 hour hypoxia + 2 hour reoxygenation versus 4 hour hypoxia only. This fact suggests that reoxygenation occurred during the susceptible period of hepatocyte for this injury. LITTAUER and De GROOT $^{(34)}$ showed the existence of a vulnerable period of hepatocyte injury by reoxygenation after hypoxia in a study on primary hepatocyte cultures. We also showed this vulnerable period in our model in a previous study ${ }^{(4)}$. In this study the hepatocyte lesion due to reoxygenation after 2 and 3 hour of hypoxia was a significantly worse, but not after 4 and 6 hour hypoxia (data unshown).

Previous hypoxia was necessary to sensitize the cell to be damage lesion by reoxygenation, because in hepatocytes after 2 hour oxygenation without hypoxia the lesion was not worse than in the control group. The lesion of the hepatocyte submitted to hypoxia and reoxygenation was evident, but 2 hour hypoxia not followed by reoxygenation did not show significant lesion on the cultured hepatocytes. This phenomenon may be due to production of OFRs by mitochondria. Higher production of superoxide radicals by mitochondria occurs when the carriers of the respiratory chain are reduced in hypoxia state and the available ADP is reduced $^{(13,17,64)}$. It is possible that hypoxia allows a greater production of OFRs also from cytoplasm sources such as $\mathrm{XO}$ that is formed from the xanthine dehydrogenase (XD) in hypoxia microenvironment ${ }^{(35)}$.

Among the cytoprotectors under study, PGE1 and SOD presented more remarkable results in terms of the two functional criteria employed, with the groups submitted to $\mathrm{SH}$ and $\mathrm{H}+\mathrm{R}$ not differing from the control group. Moreover, the two substances significantly reduced the lesion of the $\mathrm{SH}+\mathrm{PGE} 1$, $\mathrm{SH}+\mathrm{SOD}, \mathrm{H}+\mathrm{R}+\mathrm{PGE} 1$ and $\mathrm{H}+\mathrm{R}+\mathrm{SOD}$ groups compared with the $\mathrm{SH}$ and $\mathrm{H}+\mathrm{R}$ groups. Although the mechanism of cytoprotection of PGs is not fully understood, some stages of their cellular action have been investigated. PGs derive from arachidonic acid through the action of phospholipase A2 (PLA2) on the membrane phospholipids. PGs seem to stabilize the lysosomal membrane $e^{(31,48,52)}$ and may also preserve the cell membranes as a whole. It is possible that PGs are produced in the cells by hypoxic stress. WANG et al. ${ }^{(59)}$ studied the effect of chemical hypoxia in cultured hepatocytes and found an increase of messenger RNA toward type II PLA2 in cells and also an increase of arachidonic acid liberation. It is equally possible that high levels of type II PLA2 occur in hypoxia and hypoxia + reoxygenation microenvironments, causing an increase of arachidonates. However, for unknown reasons, PGs may not be produced at the same proportion resulting in the loss of hepatocyte viability.

PGs also stimulate adenyl cyclase enzyme on the hepatocyte membrane and raise the intracellular levels of cAMP $^{(48)}$. cAMP appears to inhibit the liberation of lysosomal enzymes ${ }^{(24,}$ 60), reducing in this way one of the main components of cell lesion by $\mathrm{H}$ and $\mathrm{H}+\mathrm{R}$ injury. $\mathrm{PGs}$ might interfere with calcium homeostasis due to the increase of cAMP levels, which seems to inhibit phospholipase $\mathrm{C}$ leading to the reduction of second messengers IP3 and DAG with a loss of calcium mobilization from the intracellular stores ${ }^{(49)}$. NAKANO et al. ${ }^{(41)}$ observed in a model of primary culture of hepatocytes under exposure to superoxide radicals that Prostaglandin $I_{2}$ analogues prevented the increase of intracellular calcium in a dose-dependent manner. HELLING et al. ${ }^{(22)}$ questioned the relation between PGs and calcium balance. These authors worked with a pig liver ischemia model, and they did not find a significant difference in the ionized calcium blood level in the animals that received PGE1 transfusion.

The mechanism of the cytoprotective effect of PGs in a reoxygenation environment is not fully clear. We showed that PGE1 do not prevent the hydroperoxides formation in reoxygenation after hypoxia. This result is similar to the other studies $^{(10,21)}$. QUINTERO et al..$^{(47)}$ did not find modulation of free radical production with PGE1 in D-galactosamine injury in spite to its ability to abolish the GSH depletion. PGs also do not induce inhibition of $\mathrm{XO}^{(56)}$. It is possible that the improvement of mitochondrial function is one of the reasons for the cytoprotective action of PGs in a reoxygenation environment ${ }^{(10,32)}$. UEDA et al. ${ }^{(58)}$ obtained 
with PGE1 the ATP restoration to $80 \%$ of the pre-ischemic level 2 hours after reflux as compared with $55 \%$ in the control group. KUROKAWA et al. ${ }^{(32)}$ showed that infusion of PGE1 accelerated the recovery of mitochondrial function after reperfusion in the model of hepatic ischemia. GHUMAN et al. ${ }^{(18)}$ and SIKUJARA et al. ${ }^{(52)}$ also observed a faster recovery of ATP in ischemic livers during reperfusion with PGs. MALMSTROM and CARAFOLI ${ }^{(36)}$ found an interesting relation between PGs and mitochondrial calcium. The PGs studied produced calcium efflux from mitochondria without damaging the capacity of the organelle to retaining ion. Therefore, it is possible that PGs prevent the excessive increase of mitochondrial calcium that would provoke a noxious effect on organelles exposed to injury. In another recent study, PGE1 prevented D-galactosamine-induced hepatocyte apoptosis by a mitochondria-independent mechanism ${ }^{(51)}$.

The explanation for the cytoprotective effect of SOD in reoxygenation environments lies in its capacity to neutralize the superoxide free radical ${ }^{(64)}$. YOUNES and STRUBELT ${ }^{(63)}$ found protection of rat liver submitted to hypoxia and reoxygenation by using $20 \mu \mathrm{g} / \mathrm{mL}$ SOD. In another study, KOBAYASHI et al. ${ }^{(29)}$ employed a long acting SOD in a model of ischemia/ reperfusion and noted a better recovery of mitochondrial function compared to the group receiving no SOD.

In our study we also found a remarkable protective effect of SOD on the group under simple hypoxia. There is evidence that the hepatocytes can produce OFRs as well as hydroperoxides during simple hypoxia ${ }^{(13)}$. The carriers accumulate in a reduced state in the mitochondrial respiratory chain in a hypoxic environment. The superoxide radicals might appear from the available molecular $\mathrm{O}_{2}$ in relative hypoxia ${ }^{(13,17)}$. HENRY et al. ${ }^{(23)}$ noted OFRs production under $\mathrm{O}_{2}$ low tension in the isolate rat heart. This phenomenon could perhaps be explained by the regeneration of lipid peroxidation. $\mathrm{CHO}$ et al. ${ }^{(9)}$ observed the cytoprotective action of SOD in a model of liver ischemia when the enzyme was applied before the ischemia and reperfusion. The effects were more remarkable before ischemia and this surprised the authors. However, a full explanation for the cytoprotective effects of SOD in a simple hypoxia group requires further studies.

We found that ALO had a cytoprotective effect on hepatocytes in the group $\mathrm{H}+\mathrm{R}+\mathrm{ALO}$ as compared with $\mathrm{H}+\mathrm{R}$ group. ALO protected the simple hypoxia group only in terms of percent cell viability, indicating a questionable protective role of these substance against hypoxia. ALO has a more significant protective action in hepatocytes submitted to reoxygenation in accordance with its known effects in the blockade of $\mathrm{XO}$ enzyme ${ }^{(8)}$. However, the conversion rate of $\mathrm{XD}$ to $\mathrm{XO}$ (main XO source in cells) in a hypoxic environment is questionable. XO represents only $10 \%$ to $20 \%$ of the total activity of $\mathrm{XD}+\mathrm{XO}$ in cells under normal conditions ${ }^{(46)}$. De GROOT et al. ${ }^{(15)}$ showed that higher rates of conversion from XD to XO occurred after 4 hours of hypoxia on isolated hepatocytes when most of the cells had lost their viability. Other authors found a significant conversion of XD to XO within 2 hours of ischemia and $50 \%$ conversion within 3.6 hours ${ }^{(16)}$. However, there are doubts if the cytoprotective role of ALO in reoxygenation models is due to XO blockade or to its action as OFRs neutralizer. DAS et al. ${ }^{(12)}$ verified that a $1 \mu \mathrm{M}$ of ALO and oxipurinol neutralized the chlorine free radical as well as the hypochlorous acid in an ischemia/reperfusion model in myocardium. PARKS and GRANGER ${ }^{(46)}$ reported a neutralizing action on superoxide radicals using $500 \mu \mathrm{M}$ of ALO (about 25 times higher than the dose employed in our study). MOORHOUSE et al. ${ }^{(38)}$ obtained neutralizing effects on hydroxyl radicals by employing still higher doses of ALO $(1000$ a $1500 \mu \mathrm{M})$. In view of the high doses of ALO employed in these studies, it is improbable that these effects might contribute to the ALO cytoprotection in our work. Another explanation for the beneficial effects of ALO is the preservation of hypoxanthine as a substrate to form ATP. Hypoxanthine is preserved through the blockade of XO by ALO and can form ATP instead of uric acid during reoxygenation ${ }^{(35,44)}$. CUNNINGHAM et al. ${ }^{(11)}$ noted a smaller fall of ATP, AMP and ADP in a renal ischemia model and a larger recovery of ATP levels in the reperfusion group treated with ALO. NAKANO et al. ${ }^{(40)}$ also showed a faster recovery of ATP after 60 min ischemia with ALO.

We showed that VERA presented a cytoprotective role for hypoxia and hypoxia + reoxygenation groups. VERA can block the calcium influx to hepatocytes through block of calcium channels receptor-operated (ROCs) present in hepatocytes ${ }^{27,50,}$ 63). Some studies showed a correlation between the increase of intracellular calcium and the stress oxidative injury ${ }^{(39)}$. VERA may also inhibit the overload of mitochondrial calcium, both in ischemia and reperfusion ${ }^{(43)}$, as well as to prevent the $\mathrm{XD}$ to $\mathrm{XO}$ conversion in the cytoplasm ${ }^{(25)}$.

The objective of the present study was to find therapeutic options for hepatocytes submitted to hypoxia and hypoxia + reoxygenation injury. We think that the substances prostaglandin E1, superoxide dismutase, allopurinol and verapamil are effective cytoprotectors of hepatocytes exposed to oxidative stress. We are sure that future focus on the treatment of serious hepatic diseases should concentrate on hepatocyte cytoprotection as a complement to the combat of the aggressive factors (infectious and immunological). The substances investigated here are options deserving attention in future studies. This research may contribute for the therapeutical employ of these substances in human being increasing the options for the treatment of acute and chronic hepatic diseases. 
Andrade Jr DR, Andrade DR, Santos SA. Study of rat hepatocytes in primary culture submitted to hypoxia and reoxygenation: action of the cytoprotectors prostaglandin E1, superoxide dismutase, allopurinol and verapamil

Andrade Jr DR, Andrade DR, Santos SA. Estudo de hepatócitos de rato em cultura primária submetidos a hipóxia e reoxigenação: ação dos citoprotetores prostaglandina E1, superóxido dismutase, alopurinol e verapamil. Arq Gastroenterol. 2009;46(4):333-40.

RESUMO - Contexto - A exposição dos hepatócitos a condições patológicas em que ocorram microambientes de hipóxia e reoxigenação são muito frequentes em doenças hepáticas. Várias substâncias apresentam perspectivas de ação citoprotetora para hepatócitos submetidos a reoxigenação após hipóxia e hipóxia simples. Objetivo - Pesquisaram-se opções terapêuticas para o dano dos hepatócitos submetidos a hipóxia e hipóxia + reoxigenação. Métodos - Hepatócitos de rato em cultura primária foram submetidos a hipóxia (2 horas) mais reoxigenação (2 horas) e hipóxia simples (4 horas), na presença ou ausência dos citoprotetores. A lesão dos hepatócitos foi avaliada por critérios funcionais através da percentagem liberada de desidrogenase láctica e da viabilidade celular. Os efeitos dos citoprotetores prostaglandina E1 $3 \eta \mathrm{g} / \mathrm{mL}$, superóxido dismutase $80 \mu \mathrm{g} / \mathrm{mL}$, alopurinol $20 \mu \mathrm{M}$ e verapamil $10^{-4} \mathrm{M}$, foram estudados neste modelo de injúria celular. Resultados - A reoxigenação após hipóxia induziu lesão mais significativa nos hepatócitos cultivados comparado com hipóxia simples, conforme demonstrado pela análise dos critérios funcionais. Houve significativa redução da porcentagem liberada de desidrogenase láctica e aumento significativo da percentagem de viabilidade celular nos grupos hipóxia + reoxigenação + citoprotetores em comparação com o grupo hipóxia + reoxigenação. Prostaglandina E1, superóxido dismutase e verapamil também protegeram o grupo hipóxia simples, quando avaliado pelos critérios funcionais. Conclusões - Conclui-se que a reoxigenação após hipóxia aumentou significativamente a lesão dos hepatócitos de rato cultivados, em comparação com a hipóxia simples. Prostaglandina E1, superóxido dismutase, alopurinol e verapamil foram citoprotetores para os hepatócitos de rato submetidos a hipóxia + reoxigenação in vitro. As substâncias prostaglandina E1, superóxido dismutase e verapamil protegeram os hepatócitos submetidos a hipóxia simples com base em todos os critérios estudados neste modelo experimental.

DESCRITORES - Hepatócitos. Hipóxia celular. Prostaglandinas E. Superóxido dismutase. Alopurinol. Verapamil. Ratos.

\section{REFERENCES}

1. Abecassis M, Falk JA, Makowka L, Dindzans VJ, Falk RE, Levy GA. 16,16 dimethyl prostaglandin E2 prevents the development of fulminant hepatitis and blocks the induction of monocyte/macrophage procoagulant activity after murine hepatitis virus strain 3 infection. J Clin Invest. 1987;80:881-9.

2. Alp MH, Hickman R. The effect of prostaglandins, branched-chain amino acids and other drugs on the outcome of experimental acute porcine hepatic failure. $\mathrm{J}$ Hepatol. 1987:4:99-107.

3. Andrade Jr DR. Estudo de hepatócitos de rato em cultura primária in vitro submetidos à hipóxia: análise da lesão celular e do papel citoprotetor da prostaglandina E1 [dissertação]. São Paulo: Instituto Brasileiro de Estudos e Pesquisas de Gastroenterologia - IBEPEGE; 1992. 85p

4. Andrade Jr DR, Ori M, Andrade DR. Detecção de período vulnerável para lesão de hepatócito de rato em cultura primária, submetido à reoxigenação após períodos variáveis de hipóxia. Rev Soc Bras Med Trop. 1994;27:423.

5. Berger ML, Reynolds RC, Hagler HK, Belloto D, Parsons D, Mulligan KJ, Buja LM. Anoxic hepatocyte injury: role of reversible changes in elemental content and distribution. Hepatology. 1989;9:219-28.

6. Beutler E. Red cell metabolism: a manual of biochemical methods. 3rd ed. New York: Grune \& Stratton, 1984

7. Caraceni P, Rosenblum ER, Van Thiel DH, Borle AB. Reoxygenation injury in isolated rat hepatocytes: relation to oxygen free radicals and lipid peroxidation. Am J Physiol. 1994;266:g799-g806.

8. Castillo M, Pereyra LHT, Prough D, Sharpiro E, Gordon D, Choudhury S. Effective timing of allopurinol administration in the ischemic liver. Transplantation. 1989;47:727-30.

9. Cho WH, Kim DJ, Murase N, Mishinger HJ, Todo S, Starzl TE. Comparison of superoxide dismutase, allopurinol, coenzyme Q10 and glutathione for the prevention of warm ischemic injury. Transplantation. 1990;50:353-5.

10. Colletti LM, Burtch GD, Campbell DA. Prostaglandin E2 protects the isolated perfused rabbit liver from an oxygen free radical - induced injury. Transplant Proc. 1990;22:2381-3.

11. Cunningham SK, Keaveny TV, Fitzgerald P. Effect of allopurinol on tissue ATP, ADP and AMP concentrations in renal ischemia. Br J Surg. 1974;61:562-5.

12. Das DK, Engelman RM, Clement R, Otani H, Prasad MR, Rao OS. Role of xanthine oxidase inhibitor as free radical scavenger: a novel mechanism of action of allopurinol and oxypurinol in myocardial salvage. Biochem Biophys Res Commun. 1987;148:314-9.

13. Dawson TL, Gores GJ, Nieminen AL, Herman B, Lemasters JJ. Mitochondria as a source of reactive oxygen species during reductive stress in rat hepatocytes. Am J Physiol. 1993;264:c961-c7.

14. Deakin CD, Fagan EA, Williams R. Cytoprotective effects of calcium channel blockers. Mechanism and potential applications in hepatocellular injury. J Hepatol. 1991;12:271-81.
15. De Groot H, Anundi I, Littauer A. Hypoxia-reoxygenation injury and the generation of reactive oxygen in isolated hepatocytes. Biomed Biochim Acta. 1989;48:s11-s5.

16. Engerson TD, McKelvey TG, Rhyne DB, Boggio EB, Snyder SJ, Jones HP. Conversion of xanthine dehydrogenase to oxidase in ischemic rat tissues. J Clin Invest. 1987:79:1564-70.

17. Freeman BA, Crapo JD. Free radicals and tissue injury. Lab Invest. 1982;47:41226.

18. Ghuman SS, Rush BF, Machiedo GW, Loverme PJ, Kraven T, Dikdan G. Effect of prostaglandin on cell membrane permeability and hepatic high-energy stores following hemorrhagic shock. J Surg Res. 1982;32:484-8.

19. Glinsmann WH, Ericsson JLE. Observations on the subcellular organization of hepatic parenchymal cells. II. Evolution of reversible alterations induced by hypoxia. Lab Invest. 1966;15:762-77.

20. Gores GJ, Flarsheim CE, Dawson TL, Nieminen AL, Herman B, Lemasters JJ. Swelling, reductive stress, and cell death during chemical hypoxia in hepatocytes Am J Physiol. 1989;257:c347-c54

21. Guarner F, Fremont-Smith M, Prieto J. Cytoprotective effect of prostaglandins on isolated rat liver cells. Liver. 1985;5:35-9.

22. Helling TS, Wogahn BM, Olson SA, Evans LS, Reddy BR, Vanway III C. The effect of prostaglandin E1 on liver adenine nucleotides and cytoplasmic enzymes in a porcine model of normothermic hepatic ischemia. Hepatology. 1995;22:1554-9.

23. Henry TD, Archer SL, Nelson D, Weir EK, From AHL. Enhanced chemiluminescence as a measure of oxygen derived free radical generation during ischemia and reperfusion. Circ Res. 1990;67:1453-61.

24. Ignarro LJ, Colombo C. Enzyme release from polymorphonuclear leukocyte lysosomes: regulation by autonomic drugs and cyclic nucleotides. Science. 1973;180:1181-3

25. Ishii K, Suita S, Sumimoto H. Effect of verapamil on conversion of xanthine dehydrogenase to oxidase in ischemic rat liver. Res Exp Med. 1990;190:389-99.

26. Jauregui HO, Hayner NT, Driscoll JL, Williams-Holland R, Lipsky MH, Galletti PM. Trypan blue dye uptake and lactate dehydrogenase in adult rat hepatocytes freshly isolated cells, cell suspensions, and primary monolayer cultures. In Vitro. 1981;17:1100-10

27. Kass GEN, LLopis J, Chow SC, Duddy SK, Orrenius S. Receptor-operated calcium influx in rat hepatocytes. J Biol Chem. 1990;265:17486-92.

28. Kawamoto S, Inoue M, Tashiro S, Morino Y, Miyauchi Y. Inhibition of ischemia and reflow-induced liver injury by an SOD derivative that circulates bound to albumin. Arch Biochem Biophys. 1990;277:160-5

29. Kobayashi Y, Nonami T, Kurokawa T, Sugiyama S, Ozawa T, Takagi H. Mechanism and prevention in ischemia-reperfusion induced liver injury in rats. J Surg Res. 1991;240:240-4.

30. Kobayashi S, Clemens MG. Kupffer cell exacerbation of hepatocyte hypoxia/ reoxygenation injury. Circul Shock. 1992;37:245-52.

31. Kurebayashi Y, Honda Y. Protection by 16,16 dimethyl prostaglandin E2 and 
dibutyryl cyclic AMP against complement-mediated hepatic necrosis in rats. Hepatology. 1991;14:545-50.

32. Kurokawa T, Nonami T, Harada A, Nakao A, Sugiyama S, Ozawa T, Takagi H. Effects of prostaglandin E1 on the recovery of ischemia - induced liver mitochondrial dysfunction in rats with cirrhosis. Scand J Gastroenterol. 1991;26: 269-74.

33. Lemasters JJ, Stemkowski CJ, Ji S, Thurman RG. Cell surface changes and enzyme release during hypoxia and reoxygenation in the isolated, perfused rat liver. J Cell Biol. 1983;97:778-86.

34. Littauer A, De Groot H. Release of reactive oxygen by hepatocytes on reoxygenation: three phases and role of mitochondria. Am J Physiol. 1992;262: g1015-g20.

35. MacCord JM. Oxygen-derived free radicals in postischemic tissue injury. N Engl J Med. 1985;312:159-63.

36. Malmstrom K, Carafoli E. Effects of prostaglandins on the interaction of $\mathrm{Ca}^{2+}$ with mitochondria. Arch Biochem Biophys. 1975;171:418-23.

37. Mizoguchi Y, Tsutsui H, Miyajima K, Sakagami Y, Seki S, Kobayashi K, Yamamoto S, Morisawa S. The protective effects of prostaglandin E1 in an experimental massive hepatic cell necrosis model. Hepatology. 1987;7:1184-8.

38. Moorhouse PC, Grootveld M, Halliwell B, Quinlan JG, Gutteridge JMC. Allopurinol and oxypurinol are hydroxyl radical scavengers. FEBS Lett. 1987;213:23-8.

39. Murata M, Monden M, Umeshita K, Nakano H, Kanai T, Gotoh M, Mori T. Role of intracellular calcium in superoxide-induced hepatocyte injury. Hepatology. 1994; 19:1223-8.

40. Nakano M, Sugano M, Terasaki M, Morimoto T, Mashima S, Mitsuyoshi A, Sasaki H, Kumada K, Ozawa K. Preserved mitochondrial function by allopurinol despite deteriorated hemodynamics in warm ischemia-damaged canine liver. Res Exp Med. 1992;192:389-99.

41. Nakano H, Monden M, Umeshita K, Murata M, Miyoshi H, Kanai T, Gotoh M, Mori T. Cytoprotective effect of prostaglandin I2 analogues on superoxideinduced hepatocyte injury. Surgery. 1994;116:883-9.

42. Nauta RJ, Tsimoyannis E, Uribe M, Walsh DB, Miller D, Butterfield A. The role of calcium ions and calcium channel entry blockers in experimental ischemiareperfusion induced liver injury. Ann Surg. 1991;213:137-42.

43. Nayler WG, Fassold E, Yepez C. Pharmacological protection of mitochondrial function in hypoxic heart muscle: effect of Verapamil, Propranolol and Methylprednisolone. Cardiovasc Res. 1978;12:152-61.

44. Nordström G, Seeman T, Hasselgren PO. Beneficial effect of allopurinol in liver ischemia. Surgery. 1985;97:679-84.

45. Okuda M, Lee HC, Kumar C, Chance B. Oxygen radical generation during ischemia-reperfusion in the isolated perfused rat liver monitored by enhanced chemiluminescence. Circul Shock. 1992;38:228-37.

46. Parks DA, Granger DN. Ischemia-reperfusion injury: a radical view. Hepatology. 1988;8:680-2

47. Quintero A, Pedraza CA, Siendones E, Kamal ElSaid AM, Colell A, Garcia-Ruiz $\mathrm{C}$, et al. PGE1 protection against apoptosis induced by D-galactosamine is not related to the modulation of intracellular free radical production in primary culture of rat hepatocytes. Free Radic Res. 2002;36:345-55.

48. Raflo GT, Wangesteen SL, Glenn TM, Lefer AM. Mechanism of the protective effects of Prostaglandin E1 and F2a in canine shock. Eur J Pharmacol. $1973 ; 24: 86-95$
49. Rana RS, Hokin LE. Role of phosphoinositides in transmembrane signaling. Physiol Rev. 1990;70:115-64

50. Ray SD, Kamendulis LM, Gurule MW, Yorkin RD, Corcoran GB. Ca ${ }^{2+}$ antagonists inhibit DNA fragmentation and toxic cell death induced by acetaminophen. FASEB J. 1993;7:453-63.

51. Siendones E, Jiménez-Gómez Y, Montero JL, Gómez-Diaz C, Villalba JM, Muntané J. PGE1 abolishes the mitochondrial-independent cell death pathway induced by D-galactosamine in primary culture of rat hepatocytes. J Gastroenterol Hepatol. 2005;20:108-116.

52. Sikujara O, Monden M, Toyoshima K, Okamura J, Kosaki G. Cytoprotective effect of prostaglandin I 2 on ischemia-induced hepatic cell injury. Transplantation. $1983 ; 36: 238-43$.

53. Sinclair SB, Greig PD, Blendis LM, Abecassis M, Roberta EA, Phillips MJ Cameron R, Levy GA. Biochemical and clinical response of fulminant vira hepatitis to administration of prostaglandin E. A preliminary report. J Clin Invest. 1989;84:1063-9.

54. Stachura J, Tarnawski A, Ivey KJ, Mach T, Bogdal J, Szczudrawa J, Klimczyc B. Prostaglandin protection of carbon tetrachloride-induced liver cell necrosis in the rat. Gastroenterology. 1981;81:211-7.

55. Stein HJ, Oosthuizen MMJ, Hinder RA. Effect of verapamil on hepatic ischemiareperfusion injury in normal and glutathione depleted rats. Gastroenterology. 1989;96:a663.

56. Suzuki H, Suematsu M, Ishii H, Kato S, Miki H, Mori M, Ishimura Y, Nishino T, Tsuchiya M. Prostaglandin E1 abrogates early reductive stress and zone specific paradoxical oxidative injury in hypoperfused rat liver. J Clin Invest. 1994;93:155-64

57. Thurman RG, Marzi I, Seitz G, Thies J, Lemasters JJ, Zimmerman F. Hepatic reperfusion injury following orthotopic liver transplantion in the rat. Transplantation. 1988:46:502-6

58. Ueda Y, Matsuo K, Kamei T, Kayashima K, Konomi K. Protective effect of prostaglandin E1 (PGE1) on energy metabolism and reticuloendothelial function in the ischemically damaged canine liver. Liver. 1989;9:6-13.

59. Wang H, Harrison-Shostak DC, Lemasters JJ, Herman B. Contribution of pHdependent group II phospholipase A2 to chemical hypoxic injury in rat hepatocytes. FASEB J. 1996;10:1318-25.

60. Weissman G, Dukor P, Zurier RB. Effect of cyclic AMP on release of lysosoma enzymes from phagocytes. Nature. 1971;231:131.

61. Wolff SP, Dean RT. Fragmentation of proteins by free radicals and its effect on their susceptibility to enzymic hydrolysis. Biochem J. 1986;234:399-403.

62. Wolff SP. Ferrous ion oxidation in presence of ferric ion indicator xylenol orange for measurement of hydroperoxides. Methods Enzymol. 1994;233:182-9.

63. Younes M, Strubelt O. The involvement of reactive oxygen species in hypoxic injury to rat liver. Res Commun Chem Pathol Pharmacol. 1988;59:369-81.

64. Yu BP. Cellular defenses against damage from reactive oxygen species. Physiol Rev. 1994;74:139-62

65. Zhong Z, Lemasters JJ, Thurman RG. Role of purines and xanthine oxidase in reperfusion injury in perfused rat liver. J Pharm Exp Ther. 1989;250:470-5.

Recebido em 11/9/2008. Aprovado em 21/3/2009. 